DOI: https://doi.org/10.15407/techned2019.05.083

\title{
COMPLEX FOR ELECTRIC POWER EQUIPMENTS MAGNETIC FIELDS MONITORING
}

$\quad$ Journal
Publisher
ISSN
Issue
Pages

Tekhnichna elektrodynamika Institute of Electrodynamics National Academy of Science of Ukraine 1607-7970 (print), 2218-1903 (online) No 5, 2019 (September/Oktober) $83-92$

\begin{abstract}
Author
R.O. Mazmanian

Institute of Electrodynamics National Academy of Sciences of Ukraine, pr. Peremohy, 56, Kyiv, 03057, Ukraine, e-mail:mazmanian@ied.org.ua
\end{abstract}

\section{Abstract}

Using characteristics of magnetic fields as diagnostic parameters is due to their direct interconnection with energy conversion processes, structural and functional features of electric power equipment, current state and modes of its operation. The cumulative effects on the diagnostic parameter lead to changes in its value, and their diversity causes differences in the nature of these changes. Analysis of the nature of these changes is used to describe diagnostic signs associated with the exposure of faults, which provides greater efficiency in detecting early signs of deviations from the normal state and greater selectivity in case of multiple faults. At the same time, monitoring of external magnetic fields of electric power equipment in various areas of their occurrence - temporal, spatial and frequency - is implemented without the objects destructing, changing the technological process or modes of their operation. The aim of the work is to develop principles of construction and operation, methods for implementing a set of tools for studying electric power equipment through continuous or periodic monitoring of magnetic fields and the use of monitoring results in technical diagnostics systems. Summary: 1. A multi-level functional specification of a system has been developed, which is implemented by its hardware and software components; 2 . The choice of primary measuring transducers is 
substantiated with factoring in the features of monitoring external and internal magnetic fields of observing objects; 3. Methods and means for software and hardware implementation of the zero-bias compensation function caused by the non-equipotentiality of the Hall transducers and the drift of the amplifier-converter circuit are proposed; 4 . The division of computing resources between programmable computing (microcontroller) devices and digital logic devices with programmable structure (CPLD) has been grounded. 5. Experimental studies of the developed system confirmed the implementation of the given functional specification. The system provides registration of induction of external and internal magnetic fields, data collection and its visualization for identification of diagnostic characteristics of electrical rotating machines. Refere nces 26, figures 5 .

Key words: magnetic measurements, monitoring, data acquisition, electric power equipment.

Received: 13.03.2019

Accepted: 06.05.2019

Published: 01.08.2019

\section{References}

1. Zabludovskiy P.E., Kruchok G.R., Kuzmin M.K., Levit M.M. History of medicine. Moskva: Meditsina, 1981. 352 p. (Rus)

2. Petuhov V. Diagnostika elektrodvigateley. Novosti elektrotekhniki. 2008. No 1 (50). Pp. 33-37.

3. Emec S., Kruger J., Seliger G. Online Fault-monitoring in Machine Tools Based on Energy Consumption Analysis and Non-invasive Data Acguisition for Improved Resource-efficsency. Pr ocedia CIPR

. 2016. Vol. 40. Pp. 236-243.

DOI:

https://doi.org/10.1016/j.procir.2016.01.111

4. Irfan M., Ibrahim R., Asirvadam V.S., Alwadie A.S., Sheikh M.A. An Assessment on the Non-Invasive Methods for Condition Monitoring of Induction Motors Fault Diagnosis and Detection. InTechOpen. 2017. Ch. 4. Pp. 87-129. DOI: http://dx.doi.org/10.5772/67917 5. Alekseenko A.Yu., Brodskiy O.V., Vedeneev V.N., Tonkih V.G., Homutov S.O.Induction motors diagnosis and state prediction with the use of external electromagnetic field parameters. Vestnik Altaiskogo gosudarstvennogo tekhnicheskogo universiteta im. I.I. Polzunova . 2006. No 2. S. 79-83. (Rus)

6. dos Santos H.F., Rigoni M., de A.Elias R., Feler L.A., Wengerkievicz C.A.C., Batistela N.J., 
,Sadowski N., Kuo-Peng P., Bastos J.P.A. Non-invasive monitoring system of synchronous generator using external field. Journal of Microwaves, Optoelectronics and Electromagnetic Applications . 2017. Vol. 16. No 1. Pp. 70-89. DOI: https://doi.org /10.1590/2179-10742017v16i1872

7. Zidat F., Lecointe J-Ph., Morganti F., Brudny J-F., Jacq T., Frederic St. Non Invasive Sensors for Monitoring the Efficiency of AC Electrical Rotating Machines. Sensors. 2010. No 10(8). Pp. 7874-7895.

DOI: http s://doi.org/10.3390/s100807874

8. Mitsubishi Electric Develops Unique Technology for Electromagnetic-field and Large-coupled Analysis of Turbine Generators. URL: http://emea.mitsubishielectric.com/en/news-events/relea ses/global/2017/0524-g/pdf/170524-g 3114 en g.pdf

(accessed 10.05.2019)

9. Mazmanian R.O.Spatial 2D monitoring in the diagnosis of electrical power equipment. Promy shlennaia energetika

. 2015. No 2. Pp. 17-20. (Rus)

10. Sidelnikov L.G., Afanasev D.O. Review of online monitoring methods for induction motors dsagnosis. Vestnik PNIPU. Geologiia. Neftegazovoe i gornoe delo. 2013. No 7. Pp. 127-137.

(Rus)

11. Titko O.I. Scientific activities and means of ensuring the reliability of power equipment. Prats i Instytutu elektrodynamiki NAN Ukrainy

. 2004. No 2(8).Pp. 158-159. (Rus)

12. Polyakov S.V., Reznikov B.I., Schennikov A.V., Kopytenko E.A., Samsonov B.V. The range of induction-coil magnetic field sensors for geophysical explorations. Seismicheskie pribory. 2016. Vol. 52. No 1. Pp. 5-27. (Rus)

13. Krupa N.N., Skirta Yu.B., Sharay I.V. Compact magnetic field sensors based on thin foil from amorphous cobalt alloys MM-3So, MM-5So and NiMnGa martensitic crystals. Uspekhi fiziki metallov

. 2014. Vol. 15. S. 101-120. (Rus)

DOI:

https://doi.org/10.15407/ufm.15.03.101

14. Allegro Hall-Effect Sensor ICs. URL: https://www.allegromicro.com/en/Design-Center/Tech nical-Documents/Hall-Effect-Sensor-IC-Publications/Allegro-Hall-Effect-Sensor-ICs.aspx

. (accessed 10.05.2019)

15. Infineon. Pocket guide 2018. Infineon Technologies AG. URL: https://www.infineon.com/dg dl/Infineon-Sensor Solutions\%20Pocket\%20Guide-PC-v01 01-EN.pdf?fileld =5546d462636cc 8fb016422aea1671cc0 (accessed 10.05.2019)

16. Steiner R., Maier Ch., Haberli A., Steiner F.-P., Baltes H. Offset reduction in Hall devices by continuous spinning current method. Sensors and Actuators. 2000. A, 85. Pp. 9-17.

17. Brayko V.V., Grinberg I.P., Kovalchuk D.V., Taranov S.G. Galvanomagnetic transducers in measurement technology. Moskva: Energoatomizdat, 1984. 360 p. (Rus)

18. MultiDimension Technology. URL: http://www.dowaytech.com/en/ (accessed 10.05.2019)

19. Asahi Kasei Microdevices (AKM). URL: https://www.akm.com/akm/en/featured/ . (accessed 10.05.2019)

20. Honeywell. Aerospace. URL: https://aerospace.honeywell.com/en/products/navigation-andsensors/small-size-axis-analog-magnetic-sensors . (accessed 
10.05.2019)

21. Voss A., Bartos A. Scalable linear magneto resistive sensor arrays. GMA/ITG-Fachtagung Sensoren und Messsysteme. 2016-05-10 - 2016-05-11 Pp. 195-199. (accessed 10.05.2019) 22. 488.2-1992 IEEE Standard Codes, Formats, Protocols, and Common Commands for Use With IEEE Std 488.1-1987, IEEE Standard Digital Interface for Programmable Instrumentation. URL: http://webuser.unicas.it/misure/MAQ_OLD\%20(VO)/Dispense/DISP_7STANDARD\%20IE EE\%20488 2\%20192.pdf (accessed 10.05.2019)

23. Brodin, V.B., Shagurin, I.I. Microcontrollers. Architecture, programming, interface. Moskva: EKOM, 1999. 400 p. (Rus)

24. ISE In-Depth Tutorial UG695. (v13.1) March 1. 2011 URL: https://www.xilinx.com/support/d ocumentation/sw manuals/xilinx13 1/ise tutorial ug695.pdf (accessed 10.05.2019)

25. Brown S., Rose J. Architecture of FPGAs and CPLDs: A Tutorial URL: http://www.eecg.tor onto.edu/ jayar/pubs/brown/survey.pdf

(accessed 10.05.2019)

26. National Instruments. URL: http://www.ni.com/ru-ru/shop/labview.html (accessed 10.05.2019)

$\underline{\text { PDF }}$ 